UDC 634.13-152.6(497.7)

Original research paper

doi: 10.5937/AASer1846277S

Acta Agriculturae Serbica, Vol. XXIII, 46 (2018); 277-284

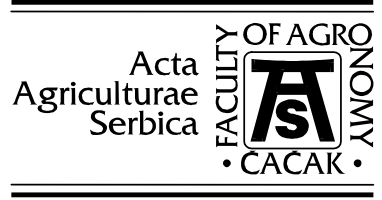

\title{
Differentiation of mixed flower buds in some traditional pear varieties in the region of Skopje
}

\author{
Ana Selamovska ${ }^{1}$, Elizabeta Miskoska-Milevska ${ }^{2 *}$ \\ ${ }^{1}$ Institute of Agriculture, Ss. Cyril and Methodius University, Skopje, Republic of \\ Macedonia \\ ${ }^{2}$ Faculty of Agricultural Science and Food, Ss. Cyril and Methodius University, \\ Skopje, Republic of Macedonia \\ *Corresponding author: miskoska@yahoo.com
}

\begin{abstract}
The results in the present paper are part of the scientific research project "Autochtonous genetic resources of pears in the Republic of Macedonia". Flower bud differentiation was examined in five traditional pear varieties ('Carigradsko Avche', 'Letna Kajkushka', 'Vodenka', 'Zimska Kajkushka' and 'Zimnica') in the region of Skopje. In the region of Skopje, the differentiation of mixed flower buds in the traditional pear varieties starts in summer. The primordia of calyx and corolla are formed in the period from the second half of October to early November. In midNovember, stamen primordia are formed, while in late November the primordia of carpels are formed. In winter months, the archesporial tissue develops and microsporogenesis occurs. In the period from January to March, microgametogenesis and pollen grain development take place. The earliest differentiation of flower buds (approximately 7-10 days) and the earliest blooming (about 3-4 days) are tipical of the variety 'Carigradsko Avche', compared to the latest varieties 'Zimska Kajkushka' and 'Zimnica'.
\end{abstract}

Keywords: differentiation, mixed flower buds, pear, traditional varieties. 


\section{Introduction}

During its life, the flower bud passes through the so-called small, incomplete annual cycle, including the processes of transition from vegetative bud to the generative stage. It is part of the great cycle of ontogenesis. In some periods, under certain environmental conditions, in the armpit of the vegetative buds, meristem tissues transform into the generative stage. From formation until dying, the meristem goes through a complex life path or through three periods of vegetation. In the first year of vegetation, the bud occurs; in the second year the vegetative bud transforms into the generative stage; and in the third year blooming, fertilisation and ripening of fruits occur (Kuperman, 1968; Vitkovskii, 1984; Romanovskaya and Baksiene, 2007).

The final stage of the ontogenesis cycle involves the formation and differentiation of flower buds. Organogenesis in Angiospermae (Magnoliophyta) (small cycle of ontogeneses) occurs in 12 phases, under following a specific order (Kuperman, 1968; Vitkovski, 1984; Isaeva (cit. according to Luchic at al., 1995)). Differentiation occurs in 4 phases: induction ( occurring in the leaves after their emergence), initiation (physiological and chemical changes in the bud); differentiation and development of flower organs in the bud (internal invisible changes called microphenophases - I to VIII) and the development of flower organs outside buds (visible changes - phenophases IX to XII).

Seasonal rhythm and the place and time of flower bud formation are specific to each plant species and it happens under natural cycle rules (Ansimov et al., 2003). Many factors affect the differentiation of flower buds, such as genotype and climatic conditions (Kuperman, 1968; Per'fileva, 1970; Mihailov and Topchiiski, 1975; Marafon et al., 2010; Selamovska, 2007; Selamovska, 2013), cultivation method (Bertelsen, 2005); nutrition (Qinazhi and Bingzhen, 2000; Ito et al., 2002), age of plant (Luchic et al., 1995; Reynolds et al., 2005), length of day (Selamovska, 2007), altitude, latitude (Darrow, 1966; Vitkovskii, 1984; Pirlak et al., 2002), type of planting material (Selamovska, 2007; Selamovska, 2013a) etc.

Basically, the factors that lead to the differentiation of flower buds are divided into exogenous and endogenous. The theories that attempt to answer this question are divided into four groups: genetic, morphological-anatomical, ecological and chemical (Luchic et al, 1995; Selamovska, 2007; Sestras et al., 2008). According to Qinazhi and Bingzhen (2000), the beginning of morphological changes of apical meristem in the bud is correlated with the increased concentration of amino acids in the leaves.

The pear is a fruit species which forms mixed buds with differentiated rudiments of flowers on the top of the growth cone. This type of mixed buds is also present in apple, medlar, and winter pear "Oskorusha”, walnut, hazel, 
pomegranate and citrus. In pear, at first, terminal bud starts to differentiate, followed by lateral buds (Luchic et al., 1995; Sestras et al., 2008).

Knowledge of the period of flower bud differentiation has great practical significance, because it is important for appropriate selection of varieties for suitable climatic conditions and regions, as well as for the implementation of suitable cultural and tree management practices.

\section{Material and methods}

The investigations were conducted in the region of Skopje. Skopje valley is situated at $41^{\circ} 57^{\prime} \mathrm{N}$ and $21^{\circ} 28$ 'S. Samples of traditional pear varieties (Selamovska, 2013b) were found at the foot of Skopska Crna Gora Mount, near Skopje. According to Filipovski et al. (1996), the region of Skopje belongs to the continental - Mediterranean - climate - vegetation and soil area, which combines the impact of East - Mediterranean and continental climates. Moderate cold and humid winters, as well as hot and dry summers are typical of this region.

The average annual air temperature is $12.0^{\circ} \mathrm{C}$. This region has low average minimum temperatures and many frosty days. It features a small amount of annual rainfall ranging from $460 \mathrm{~mm}$ to $583 \mathrm{~mm}$ (on average $507 \mathrm{~mm}$ ). Aridity index by De Martonne in average amounts is 22.6 and it is particularly pronounced in July, August and September. According to all climate data, it is a dry climate area. Most forests in this climate area are destroyed and turned into farmland and pastures. Due to dry climatic conditions, typical cinnamon forest soils dominate. The relief in the research area is hilly (with slope $7-12^{\circ}$ ), with a natural pasture at the edge of a deciduous forest. The dominant soil type is red soil, fifth class.

The data about climatic factors were collected from the National Hydrometeorological Service of the Republic of Macedonia, Zajcev Rid Meteorological Station, and are presented in Table 1.

Table 1. Climatic factors

\begin{tabular}{|l|l|l|l|l|l|l|l|l|l|l|l|l|}
\hline Parameters & \multicolumn{9}{|c|}{2009} & \multicolumn{9}{|c|}{2010} & \\
\cline { 2 - 13 } & I & II & III & IV & V & VI & I & II & III & IV & V & VI \\
\hline $\begin{array}{l}\text { Average } \\
\text { monthly } \\
\text { temperatures } \\
\left({ }^{\circ} \mathrm{C}\right)\end{array}$ & 1.0 & 3.3 & 7.1 & 13.4 & 18.0 & 21.0 & 2.4 & 4.4 & 8.0 & 13.5 & 17.8 & 21.4 \\
\hline $\begin{array}{l}\text { Monthly sum } \\
\text { of } \\
\text { temperatures } \\
\text { above } 10^{\circ} \mathrm{C}\end{array}$ & 10.6 & 31.0 & 41.8 & 391.7 & 549.3 & 631.3 & 10.5 & 13.9 & 161.3 & 395.9 & 552.8 & 641.9 \\
\hline $\begin{array}{l}\text { Monthly sum } \\
\text { of rainfalls } \\
\text { (mm) }\end{array}$ & 102 & 110 & 75 & 83 & 93 & 126 & 48 & 102 & 90 & 93 & 51 & 42 \\
\hline
\end{tabular}


Individual trees are found on the slopes of the mountain, at altitudes of 650 to 800 meters. Trees exist in conditions without irrigation, fertilisation and chemical protection. All old specimens are aged 100 to 150 years, as testified by locals. Individual trees provide good yield. In this paper, 5 traditional pear varieties (Pyrus communis L.) were studied:

- 'Carigradsko Avche' - a summer variety that in the region of Skopje starts to ripen in early July, during the Orthodox holiday of St. Peter.

- 'Letna Kajkushka' - a summer variety that ripens in the last third of August, Skopje region.

- 'Vodenka' - an autumn variety that in the region of Skopje ripens in early September.

- 'Zimnica' - a winter variety whose fruits are harvested at the beginning of November and can be stored until March or even April to ripen and get ready for consumption.

- 'Zimska Kajkushka' - a winter variety whose name is linked with the Orthodox holiday of Christmas Eve. The fruits are harvested in late October or even November and kept for 2-3 months to ripen and become ready for consumption during the winter months.

The differentiation of flower buds was monitored every 15 days, starting from 15 July 2008 until April 2009. The microphenophases of flower bud development were examined, starting from the third stage (beginning of visible bud differentiation) to the end of the sixth stage (pollen grain development) and blooming. They were determined according to the pattern provided by Romanovskaja (2003) and Luchic et al. (1995). Flower buds were fixed in a fixing reagent (96\% alcohol: chloroform: acetic acid $=6: 3: 1)$ and analysed under a binocular light microscope.

\section{Results and discussion}

According to the survey, the first visible sign of the transformation from the vegetative bud into the generative stage (IIIb substage) in the analysed pear varieties can be seen in July. According to Reynoldst et al. (2005), initiation of flower buds in the pear varieties 'Forelle' and 'Rosemarie' starts a little earlier in June. The earliest morphological change in the vegetative cone is observed after the completion of differentiation of cover petals and after spreading of the meristematic top (Menzel, 2003; Luchic et al., 1995).

At the end of August and beginning of September, inflorescence axis formation starts (IV ', IV ") (Figure 1). The differentiation of inflorescence in pear mixed buds is different, depending on the order of branching of the inflorescence axis (Menzel, 2003; Luchic et al., 1995). In the second half of October, inflorescence is developed and the varieties begin to form flower organs (V stage) (Fig 2). In the second half of October until early November, the 
primordia of calyx are defined (Vb), and corolla petals are well developed (Vc). Stamen primordia $(\mathrm{Vd})$ are developed in the second half of November, and carpel primordia are developed at the end of November (Ve).

Figure 1. Start of inflorescence formation

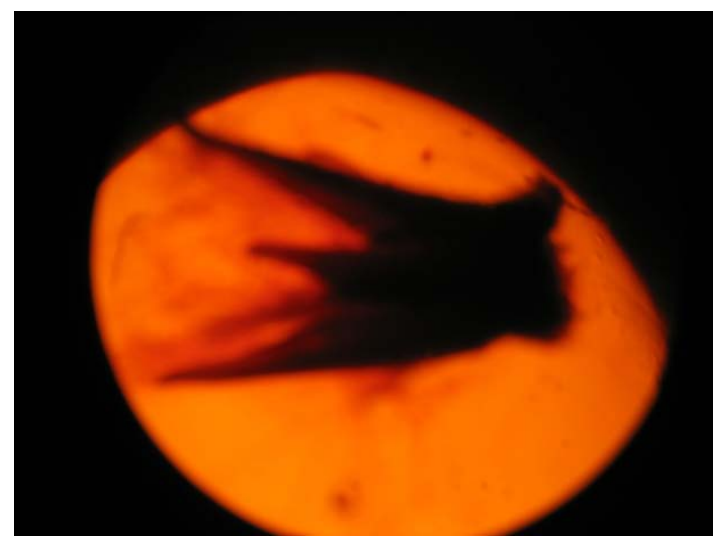

Figure 2. Developed inflorescence

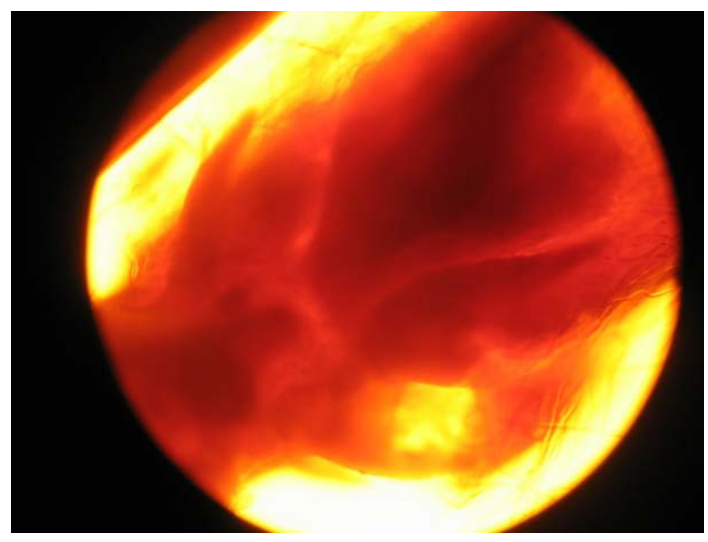

During winter, the growth and development of flower organs are completed in the buds (Vf). In early December, histological changes of differentiation take place in the archesporial tissue (VIa). During the winter months, in late December and early January, microsporogenesis occurs (VIb). In the period from January to March, pollen grains mature and develop (VIc, VId). Thus, the anthers mature and have changed greenish colour receiving red to purple - final red colour when fully ripe (Kocsisne et al., 2011). The stamens grow in height and 
later in March, the stigma is developed. This confirms that male organs are developed at first, followed by female organs, indicating that microsporogenesis occurs at first, and then macrosporogenesis follows. The phenophases of blooming and fertilisation occur during April (IX stage).

The quantity and quality of these processes are different and depend on genetic, ecological, cultural and tree management properties as well as on other factors. Considering the fact that the differentiation of varieties is followed in the same region, the early differentiation of flower buds is influenced by genotype. The earliest flower buds are differentiated in 'Carigradsko Avche'. 'Letna Kajkushka' and 'Vodenka' are next, and the latest differentiation of flower buds is characteristic of 'Zimska Kajkushka' and 'Zimnica'. The differentiation of flower buds in 'Letna Kajkushka' and 'Vodenka' occurs almost simultaneously. There is no difference in days between 'Zimska Kajkushka' and 'Zimnica' pears. According to Menzel (2000) and Perfil'eva (1970), the difference in the start of differentiation of flower buds between the earliest and latest varieties of the pear Pyrus ussuriensis is 5-10 days.

According to the average time of blooming, the analysed pear varieties in the region of Skopje started to bloom in the first third of April (10th of April). 'Carigradsko Avche' blooms the earliest (from 8th to 9th April), followed by 'Vodenka' (from 10th to 11th April) and 3-4 days later (from 12th to 13th April) by 'Letna Kajkushka', 'Zimska Kajkushka' and 'Zimnica'.

Selamovska et al. (2013a) researched blooming of the same pear varieties in different regions. In the region of Resen, 'Vodenka' and 'Zimska Kajkushka' blossom 15 to 20 days later compared to Skopje. The latest blooming is characteristic of the regions of Berovo and Pehchevo at the beginning of May. Reasons for earlier blooming of varieties in the Skopje region compared with other regions are climatic conditions, higher temperature and lower rainfalls (Selamovska and Nikolic, 2012; Selamovska et al., 2012; Selamovska et al., 2013a; Selamovska et al., 2013b).

In 2010, the differentiation of flower buds in the studied pear varieties occurred 7-10 days earlier than in 2009. The reasons for this were higher average monthly air temperatures $\left(0.6^{\circ} \mathrm{C}\right)$, a higher monthly sum of air temperatures, above $10^{\circ} \mathrm{C}$ (by 120.6), and a smaller sum of rainfalls (by 163mm) from January to the beginning of flower bud differentiation in July. In warmer and more arid conditions, organogenesis and microsporogenesis take place earlier (Selamovska and Nikolic, 2012; Selamovska et al., 2012; Selamovska et al., 2013a; Selamovska et al., 2013b).

\section{Conclusions}

The first visible sign of the transformation from the vegetative bud into the generative stage of the analysed pear varieties can be seen in the summer period, in July. The earliest flower bud differentiation is characteristic of 'Carigradsko 
Avche’, followed by 'Vodenka', 'Letna Kajkushka', 'Zimska Kajkushka' and 'Zimnica'. Differentiation of flower buds in 'Letna Kajkushka' and 'Vodenka' occurs simultaneously as in 'Zimska Kajkushka' and 'Zimnica'. The differentiation of flower organs lasts until early December.. During the winter months of December and January, the archesporial tissue is developed and microsporogenesis occurs. In the period from January to March, microgametogenesis and pollen grain development take place.

In the region of Skopje, the examined pear varieties bloom in the first third of April (10 $10^{\text {th }}$ April). The earliest blooming variety is 'Carigradsko Avche' (8th and 9th April), and the latest blooming variety is 'Zimska Kajkushka' and 'Zimnica' that bloom 3-4 days later ( $12^{\text {th }}$ and $13^{\text {th }}$ April).

Early differentiation is positively correlated with higher temperatures and negatively correlated with rainfalls.

\section{References}

Ansimov O. A., Beloluckaja M.A., Lobanov, V.A. (2003): Modern changes of a climate in the field of high breadthes of Northern hemisphere. Meteorology and hydrology, 1: 18-31.

Bertelsen M. (2005): Reflective mulch improves fruits size and flower bud formation of pear cv"Clara Friis”. Acta horticulturae, 671: 477-480.

Darrow G.M. (1966): The strawberry. History, Breeding and Physiology. Holt, Rinehart and Winston, New York, NY.: 447 pp.

Filipovski Gj., Rizovski P., Ristevski P. (1996): Characteristics of climate-vegetativesoils zones (regions) in Republic of Macedonia. MASA, Skopje.

Ito A., Hayama H. Kashimura Y. (2002): Sugar metabolism in buds during flower bud formation: a comparison of two Japanese pear (Pyrus pyrifolia Burn. nak) cultivars possessing different flowering habits. Scientia horticulturae, 96 (1-4): 163-175.

Kossisne G.M., Kocsis L., Szabó Z., Nyèki J., Soltèsz M. (2011): Evaluation of regional cultivars in a pear gene bank in Hungary. Acta Horticulturae (ISHS), 909: 201-206.

Kuperman F.M. (1968): Morfofiziologii rastenii. Izdatelstvo visao shkola. Moskva

Luchic P., Gjuric G., Micic N. (1995): Fruit Growing. Nolit. Beograd.

Marafo A.C., Herter F G., Hawerroth F.J., Silva, A.S. (2010): Floral bud initiation and development of three pear tree (Pyrus sp.) cultivars in two subtropical regions during the summer period. Acta hortuculturae, 872 (8): 291-316.

Menzel A. (2000): Trends in phenological phases in Europe between 1951 and 1996. International Journal of Biometeorology, 44 (2): 76-81.

Menzel A. (2003): Plant Phenological Anomalies in Germany and their Relation to Air Temperature and NAO. Climatic Change, 57 (3): 243-263.

Mihalov C., Topchiiski, S. (1975): Researches of micro sporogenesis in some fruit species, apple and pear. Gradinarska i lozarska nauka, 8, Sofia.

Perfil'eva Z.N. (1970): Differentiation of flower buds of pear. Nauch, tr. Omsk.Sin-t; 81: 3-15.

Pirlak L., Guleryuz M., Bolat J. (2002:) The altitude affects the runner plant production and quality in strawberry cultivars. Acta Horticulturae, 567: 305-308. 
Qinazhi M., Bingzhen L. (2000): The variations of amino acids in leaves of apple-pear tree during the period of flower bud differentiation. Journal of inner Mongolia Agricultural University (Natural Science edition), 21 (3): 26-29.

Reynolds L.P., Jacobs G., Theron, K.I. (2005): Reproductive bud development of pears (Pyrus communis L.) with emphasis on the bourse shoot. Acta Horticulturae, 671: 171-176

Romanovskaja D. (2003): Development regularities of the plants-indicators of the beginning of phenological seasons in Lithuania during 1961-2000. Agriculture Scientific articles, 84 (4): 150-164.

Romanovskaja D., Baksiene E. (2007): Influence of a thermal mode on the seasonal phenological phenomena in Lithuania. Ekologija, 1: 15-20.

Selamovska A. (2007) Differentiation and development of strawberry mixed flower buds in region of Skopje. Zaduzbina Andrejevic, Belgrade.

Selamovska A., Nikolic K. (2012): Traditional pear varieties in Republic of Macedonia. Proceedings 2, „Ecology, health, work and sport“: 374-378.

Selamovska A., Karakashova Lj., Nikolic Z. (2012): Winter traditional pear varieties in Republic of Macedonia. Proceedings, „Ecology, health, work and sport“, 2: 379-383.

Selamovska A. (2013a): Differentiation and development of strawberry mixed flower buds. Lambert Academic Publishing, Germany.

Selamovska A. (2013b): Traditional pear varieties in Republic of Macedonia. Alfa, 94, Skopje.

Selamovska A., Kratovalieva, S., Nikolic K. (2013a): Interaction of environment conditions and genotypes on expression of genetic background in micro-phenophases of strawberry mixed flower bud. Genetika, 45 (1): 181-188.

Selamovska A., Miskoska-Milevska, E., Najdenovska, O. (2013b): Genetic resources of traditional pear varieties in the region of Skopje. Contributions Sec. Nat. Math. Biotech.Sci., 34 (1-2): 93-100.

Sestras A., Sestras E., Barbos A., Haesan E. (2008): Arvena - A new pear cultivar obtained at fruit research station Cluj, Romania. Bulletin of the University of Agricultural Science \& Veterinary, 65 (1): 467.

Vitkovskii V.L. (1984): Morfogenez plodovih rastenii. Kolos, Leningrad. 